\title{
MICROORGANISMS AS BIOINSECTICIDES; SHORT REVIEW
}

\begin{abstract}
*Isah, U., Raubilu, I. A. and Ahmad M. A.
Department of Microbiology Bayero University Kano

*Corresponding Author: isahusman260@gmail.com (+2348030560631)

\section{ABSTRACT}

Hundred thousand tons of chemical insecticides are used annually in Nigeria to combat insect disease vectors especially agricultural pests, but this sort of vector control method is gradually being substituted due to their environmental effects on non-target beneficial insects especially vertebrates through contamination of food and water. To counteract this contamination, attention, efforts and researches were directed to the use of biological control agents including insect pathogens. As a result, the use of bio insecticide, as a component of integrated pest management (IPM), has been gaining acceptance over the world. Microbial pathogens comprise of organisms which cause disease, these organisms are disseminated in the pest population in large quantity in a manner similar to application of chemical pesticides. Insects like other organisms are susceptible to a variety of diseases caused by different groups of microorganisms including virus, bacteria, fungi, protozoa and nematodes. Microbial pathogens of insects are intensively investigated to develop environment friendly pest management strategies in agriculture. Microbial insecticides represent today the best alternative to chemical insecticides in controlling insect pests, they are safe for non-target species and human health are believed to show low persistence in the environment. This short review indicates that microbial insecticides are the safe alternative way possessing all the requirements to replace chemical insecticides hence, they can be utilized in pest management and control.

Keywords: Bio-insecticides, Microorganisms, biological control, pest, chemical insecticides
\end{abstract}

\section{INTRODUCTION}

Microbial pathogens consist of disease causing organisms, which are disseminated in the pest population in large quantity in a manner similar to application of chemical pesticides. These pathogens are exploited for biological control of insect pests through introductory or inundative applications. Insects like other organisms are susceptible to a variety of diseases caused by different groups of microorganisms including viruses, bacteria, fungi, protozoans and nematodes. Microbial pathogens of insects are intensively investigated to develop environment friendly pest management strategies in agriculture. In the present day plant protection scenario, development of resistance to chemicals and residue in higher trophic level are major hurdle in insect pest management. In the recent years, biopesticides are replacing the chemical pesticides to overcome the harmful effects of the chemicals on non-target organisms (Kachhawa, 2017).

Pesticides that include insecticides, herbicides, and fungicides are employed in modern agriculture to control pests and to increase crop yield. In both developed and developing countries, the use of chemical pesticides has increased dramatically during the last few decades. Control of pests with synthetic chemicals results in several problems. The residues of these synthetic insecticides cause toxic effects on wild life (e.g. Birds, beneficial insects like honeybees) (Canan, 2015). These chemical insecticides also induce harmful chemical changes on non-target insects/pests, their predators or parasites, etc.; they can also be harmful to humans and domestic animals. Other environmental concern is the contamination of ground water (Lacey, 2000).

A microbial toxin can be defined (Canan, 2015) as a biological toxin material derived from a microorganism, such as a bacterium or fungus. Pathogenic effect of those microorganisms on the target pests are so species specific. The effect by microbial entomopathogens occurs by invasion through the integument or gut of the insect, followed by multiplication of the pathogen resulting in the death of the host, e.g., insects. Studies have demonstrated that the pathogens produce insecticidal toxin important in pathogenesis. 
Special Conference Edition, November, 2019

Most of the toxins produced by microbial pathogens which have been identified are peptides, but they vary greatly in terms of structure, toxicity and specificity (Burges, 1981). II Many organisms have been investigated as potential agents for pest control, including viruses, fungi, bacteria, protozoa, nematodes, plants, invertebrate predators and fish. This review paper focuses on the insecticidal properties of microbes and their potential utility III. in pest management.

\section{Advantages of microbial insecticides}

I. The organisms used in microbial insecticides are essentially nontoxic and nonpathogenic to wildlife, humans, and other organisms not closely related to the target pest. The safety offered by microbial insecticides is their greatest strength.

II. The toxic action of microbial insecticides is IV. often specific to a single group or species of insects, and this specificity means that most microbial insecticides do not directly affect beneficial insects (including predators or parasites of pests) in treated areas.

III. If necessary, most microbial insecticides can be used in conjunction with synthetic chemical insecticides because in most cases the microbial product is not deactivated or damaged by residues of conventional insecticides. (Follow label directions concerning any limitations).

IV. Because their residues present no hazards to humans or other animals, microbial insecticides can be applied even when a crop is almost ready for harvest.

V. In some cases, the pathogenic microorganisms can become established in a pest population or its habitat and provide control during subsequent pest generations or seasons.

VI. They also enhance the root and plant growth by way of encouraging the beneficial soil microflora. By this way they take a part in the increase of the crop yield (Usta, 2015).

Disadvantages of microbial insecticides

I. Because a single microbial insecticide is toxic to only a specific species or group of insects, each application may control only a portion of the pests present in a field and garden. If other types of pests are present in the treated area, they will survive and may continue to cause damage. Conventional insecticides are subject to similar limitations because they too are not equally effective against all pests. This is because of selectivity indeed and this negative aspect is often more noticeable for both general predators, chemicals and microbials. On the other hand predators and chemicals may be dangerous for other beneficial insects in threatened area.

Heat, desiccation (drying out), or exposure to ultraviolet radiation reduces the effectiveness of several types of microbial insecticides. Consequently, proper timing and application procedures are especially important for some products.

Special formulation and storage procedures are necessary for some microbial pesticides. Although these procedures may complicate the production and distribution of certain products, storage requirements do not seriously limit the handling of microbial insecticides that are widely available. Store all pesticides, including microbial insecticides, according to label directions.

Because several microbial insecticides are pest-specific, the potential market for these products may be limited. Their development, registration, and production costs cannot be spread over a wide range of pest control sales. Consequently, some products are not widely available or are relatively expensive (several insect viruses, for example) (Slamet, 2015).

\section{Types of Microbial insecticides Entomopathogenic Bacteria}

Various bacterial species and subspecies, especially Bacillus, Pseudomonas, etc., have been established as microbial pesticides which control insect pests and plant diseases. The most salient among these are insecticides based on several subspecies of Bacillus thuringiensis Berliner. These include $B$. thuringiensis $s p$. kurstaki and $B$. thuringiensis sp. aizawai, which are highly toxic to lepidopteran larval species, and $B$. thuringiensis israelensis, with activity against mosquito larvae, black fly (simuliid) and fungus gnats. Other examples are $B$. thuringiensis tenebrionis having activity against coleopteran adults and larvae, most notably the Colorado potato beetle (Leptinotarsa decemlineata), and $B$. thuringiensis japonensis strain Buibui, with activity against soil-inhabiting beetles (Copping and Menn 2000). Bacillus thuringiensis $(B t)$ produces crystalline protein that kills specific target insect pests like lepidopteran species. Bt crystalline proteins binding with gut receptor determine the target insect pest (Kumar 2012).

Pseudomonas spp.: The renowned anti-fungal properties of root-associated bacteria of the genus Pseudomonas have been widely used for crop protection and further investigated for viable natural products in both agriculture and medicine. 
Special Conference Edition, November, 2019

The insecticidal properties of Pseudomonas entomophila, Pseudomonas

syringae and Pseudomonas fluorescens were discovered subsequently.

Pseudomonas fluorescens insecticidal toxin, or Fit, is an insecticidal proteinous toxin that causes complete loss of turgor pressure and melanization. This toxin has hemocoel-based toxicity in M. sexta, and G. mellonella (PéchyTarr eal., 2008). Based on comparisons with Pseudomonas strains not expressing the Fit toxin, Fit has been shown to be orally toxic to $S$. littoralis, $H$. virescens, and $P$. xylostella. Pseudomonas chlororaphis (Proteobacteria: Pseudomonadaceae) also expresses a Fit toxin and has oral insecticidal activity (Ruffner et al., 2013). A factor of $P$. fluorescens which correlates to insecticidal activity is the global regulator gene gacA. The expression of this gene influences components of the type VI secretion system (Hassan et al., 2010)

Toxicity of B. thuringiensis var israelansis (Bt $)$ and some other toxic strains is mainly due to the parasporal inclusion bodies ( $\delta$-endotoxins) produced during sporulation time. These endotoxins are assimilated by the larvae resulting in high toxicity. Bt and their subspecies produce different insecticidal crystal proteins $(\delta-$ endotoxins), and these toxins, when ingested by the larvae, damage the gut tissues resulting in gut paralysis. After that, the infected larvae stop feeding, and finally they die from the combined effects of starvation and midgut epithelium impairment (Pathak and Kumar, 2017).

Table 1 : Bt variety and their respective target pest

\begin{tabular}{cc}
\hline Bt variety & Target pest \\
\hline B. popilliae & Japanese beetle grubs \\
B. thuringiensis subsp. aizawai & Mosquito larvae \\
B. thuringiensis subsp. israelensis & Moth larvae \\
B. thuringiensis subsp. kurstaki & Mosquito and blackflies \\
B. thuringiensis subsp. tenebrionis & Lepidopteran larvae \\
B. thuringiensis subsp. galleriae & Colorado potato beetle \\
Bacillus moritai & Lepidopteran larvae \\
\hline
\end{tabular}

(Source: Kunimi, 2007; Kabaluk et al., 2010)

\section{FUNGI}

The pathogenic fungi are also an important group of microbial pest management organisms (Khachatourians 2009) that grow in both terrestrial and aquatic habitats and when specifically associated with insects are known as entomopathogenic fungi. These may be obligate or facultative, commensals or symbionts of insects. The pathogenic action depends on contact, and they infect and/or kill sucking insect pests, viz. aphids, thrips, mealy bugs, whiteflies, scale insects, mosquitoes and all types of mites (Barbara and Clewes 2003).

Beauveria bassiana, a Deuteromycete long known for its entomopathogenic properties, causes an insect disease known as white muscardine. The organism produces a number of cyclodepsipeptides such as beauvericin which may account for at least part of its toxicity to insects. Beauvericin may also have antimicrobial, cytotoxic, and apoptotic activity (Klaric and Pepeljnjak, 2005). Gliocladium virens also known as Trichoderma virens, this common, soildwelling saprophyte is useful in controlling Pythium ultimum and Rhizoctonia solani, organisms that cause damping-off disease in greenhouses. Such antifungal activity may be due partially to production of gliotoxin, a relatively nonselective antibiotic that is also immunosuppressive and moderately toxic to mammals (Lumsden and Walter, 1995). Lagenidium giganteum the genus Lagenidium is a member of the class Oomycetes. Oomycetes are not true fungi but are rather members of the kingdom Stramenopila, which also includes planktonic diatoms and multicellular seaweeds. The ability of $L$. giganteum, an aquatic saprophytic oomycete, to parasitize, and eventually kill, apart from toxin production, entomopathogenic fungi grow in body cavities of insects, tracheal system etc., thereby causing blockage leading to death e.g., Metarhizium anisopliae, mosquito larvae underscore its potential in mosquito control programs. Grooters et al. (2003) identified a Lagenidium species as the causative agent in six dogs with devastating infections characterized by cutaneous lesions, lymphadenopathies, and related conditions.

\section{Viruses}

A virus is a set of one or more nucleic acid template molecule, normally encased in a protective coat of protein or lipoprotein that is able to organize its own replication only within suitable host cells. 
Special Conference Edition, November, 2019

Viruses have been isolated from more than 1000 species of insects from at least 13 different insects order (Srivastava, 2010). Entomogenous viruses fall into two categories, viz. inclusion viruses (IV) producing inclusion bodies in the host cells and non-inclusion viruses (NIV) which do not produce inclusion bodies. The IV are further sub divided into polyhedron viruses (PV) or polyhedroses, which produce polyhedral bodies and granulosis virus which produce granular bodies. Polyhedroses could inhabit the nucleus and are called nuclear polyhedrosis viruses (NPV) or the cytoplasm which are called cytoplasmic polyhedrosis virus (CPV) (Rohrmann, 2013). Among the insect viruses found in nature, those belonging to the baculovirus family (Baculoviridae) were considered for the development of most commercial viral biopesticides (Kachhawa, 2017) When OBS organic bran syndrome (OBs) are consumed by insect, the alkaline environment of the midgut triggers the dissolution of polyhedral. (OBs) and the release of virions into the midgut lumen. (Adams et al., 1991). The virions enter the midgut cell nucleus, at which point the virus replicates within the nuclei of susceptible tissue cells and tissue susceptibility varies greatly between virus with some NPVs being capable of infecting almost all tissue types and most GVs being tissue specific replications (fat bodies cell only). The budded virus initiates infection to other tissues in the hemolymph, i.e. fat bodies, nerve cells, haemocytes, etc. The cell infected in the second round of virus replicate in the insect larva also produce budded virus but in addition occlude virus particles within polyhedral in the nucleus. The accumulation of polyhedral within the insect proceeds until the host consists almost entirely of a bag of virus. In the terminal stage of infection, the insect liquefies and thus releases polyhedral, which can infect other insects upon ingestion. A single caterpillar at its death may contain over $10^{9}$ occlusion bodies from an initial dose of 1000 (Rohrmann, 2013).

\section{Protozoa}

Protozoan pathogens naturally infect a wide range of insect hosts. Although these pathogens can kill their insect hosts, many are more important for their chronic, debilitating effects. One important and common consequence of protozoan infection is a reduction in the number of offspring produced by infected insects. Although protozoan pathogens play a significant role in the natural limitation of insect populations, few appear to be suited for development as insecticides. As an other example, the Microsporidia include species promising for biological control. Microsporidian infections in insects are thought to be common and responsible for naturally occurring low to moderate insect mortality. But these are indeed slow acting organisms, taking days or weeks to make harm their host. Frequently they reduce host reproduction or feeding rather than killing the pest outright. Microsporidia often infect a wide range of insects. Some microsporidia are being investigated as microbial insecticides, and at least one is available commercially, but the technology is new and work is needed to perfect the use of these organisms (Hoffmann, 1993).

Table 2. Microbial Insecticides: A summary of products and their uses

\begin{tabular}{|c|c|c|c|}
\hline PATHOGEN & PRODUCT NAME & HOST RANGE & USES AND COMMENTS \\
\hline \multicolumn{4}{|l|}{ FUNGI } \\
\hline Beauveria bassiana & $\begin{array}{l}\text { Botanigard } \AA, \\
\text { Mycotrol } \AA \text {, } \\
\text { Naturalis } \AA\end{array}$ & $\begin{array}{l}\text { aphids, fungus } \\
\text { gnats, mealy } \\
\text { bugs, } \\
\text { mites, thrips, } \\
\text { whiteflies }\end{array}$ & $\begin{array}{l}\text { Effective against several pests. High } \\
\text { moisture requirements, lack of storage } \\
\text { longevity, and competition with other soil } \\
\text { microorganisms are problems that remain } \\
\text { to be solved. }\end{array}$ \\
\hline $\begin{array}{l}\text { Lagenidium } \\
\text { giganteum }\end{array}$ & Laginex $\AA$ & $\begin{array}{l}\text { larvae of most } \\
\text { pest } \\
\text { mosquito species }\end{array}$ & $\begin{array}{l}\text { Effective against larvae of most pest } \\
\text { mosquito species; remains infective in the } \\
\text { environment through dry periods. A main } \\
\text { drawback is its inability to survive high } \\
\text { summertime temperatures. }\end{array}$ \\
\hline \multicolumn{4}{|l|}{ PROTOZOA } \\
\hline Nosema locustae & $\begin{array}{l}\text { NOLO Bait } \circledast, \text { Grasshopper } \\
\text { Attack } ®\end{array}$ & $\begin{array}{l}\text { European } \\
\text { cornborer } \\
\text { caterpillars, } \\
\text { grasshoppers and } \\
\text { mormon crickets }\end{array}$ & $\begin{array}{l}\text { Useful for rangeland grasshopper control. } \\
\text { Active only if ingested. Not recommended } \\
\text { for use on a small scale, such as backyard } \\
\text { gardens, because the disease is slow acting } \\
\text { and grasshoppers are very mobile. Also } \\
\text { effective against caterpillars. }\end{array}$ \\
\hline
\end{tabular}




\section{Table 2 continuous}

VIRUSES

\section{Gypsy moth nuclear} plyhedrosis (NPV)
Gypchek $®$ virus $\quad \begin{aligned} & \text { gypsy moth } \\ & \text { caterpillars }\end{aligned}$
All of the viral insecticides used for control of forest pests are produced and used exclusively by the U.S. Forest Service.

\begin{tabular}{lll}
\hline Tussock moth NPV & TM Biocontrol-1® & $\begin{array}{l}\text { tussock moth } \\
\text { caterpillars }\end{array}$ \\
\hline Pine sawfly NPV & Neochek-S® & pine sawfly larvae \\
\hline
\end{tabular}

Codling moth granulosis virus (GV) (see comments)
Commercially produced and marketed briefly, but no longer registered or available. Future reregistration is possible. Subject to rapid breakdown in ultraviolet light.

Source: (Agricultural Entomology, University of Illinois at Urbana-Champaign. ENY-275 IN081)

\section{CONCLUSION}

Current problems with the use of chemical insecticides and emphasis on low inputs sustainable agriculture have pushed the microbial agents to the fore front for use in IPM systems. The microorganism provides certain distinct advantages over many other control agents and methods. The major advantage of exploiting microorganism for pest control is their environmental safety primarily due to the host specificity of these pathogens. Research conducted by Kachhawa, (2017) showed biopesticides are replacing the chemicals

\section{REFERENCES}

Adams JR and McClintock JT. (1991). Baculoviridae, nuclear polyhedrosis viruses Part 1: Nuclear polyhedrosis viruses of insects. In Atlas of Invertebrate Viruses, Adams, J.R., Bonami, J.R., Eds.; CRC Press: Boca Raton, FL, USA, 1991; 6:87-180.

Barbara D and Clewes E (2003). Plant pathogenic Verticillium species: how many of them are there?

Burges, H.D. (1981). Safety, Safety Testing and Quality Control of Microbial Pesticides. Microbial control of pests and plant diseases. London, Academic Press Inc. 738-768.

Copping LG and Menn JJ (2000). Biopesticides: a review of their action, applications and efficacy. Pest Manag Sci 56:651-676

Grooters, A. M., Hodgin, E. C., Bauer, R. W., Detrisa, C. J., Znajda, N. R., and Thomas, R. C. (2003). Clinicopathologic findings associated with Lagenidium sp. infection in 6 dogs: initial description of an emerging oomycosis. J. Vet. Intern. Med. 17, 637-646.

Hassan, K.A.; Johnson, A.; Shaffer, B.T. Inactivation of the GacA response pesticides to overcome the harmful effect of the chemicals on non-target organism. Although microbial pathogens are potentially effective substitutes for chemical insecticides, their efficacy needs to be greatly improved at a lower cost in order to compete with synthetic insecticides. One consideration to keep in mind is that bioinsecticides are generally applied at much higher rates than some of the newest synthetic insecticides but produce less undesirable effects on human health and the environment.

regulator in Pseudomonas fluorescens Pf-5 has far-reaching transcriptomic consequences. Environ. Microbiol. 2010, 12, 899-915.

Hoffmann, M.P. and Frodsham, A.C. (1993). Natural Enemies of Vegetable Insect Pests. Cooperative Extension, Cornell University, Ithaca, NY. 63 pp.

Kabaluk JT, Svircev AM, Goette MS and Woo SG. (2010). The use and regulation of microbial pesticides in representative jurisdictions worldwide. IOBC Global. 2010, 99.

Kachhawa, D. (2017). Microorganisms as a biopesticides. 5(3), 468-473.

Khachatourians GG (2009) Insecticides, microbials. App/ Microbiol:95-109

Klaric, M. S., and Pepeljnjak, S. (2005). Bovericin: kemizam, bioloski aspekti i rasirinost. Arh. Hig. Rada Toksikol. (Arch. Ind. Hyg. Toxicol.) 56, 343-350.

Kumar S (2012) Biopesticides: a need for food and environmental safety. J Biofertil Biopestic 3:4

Kunimi Y. (2007). Current status and prospects on microbial control in Japan. J Invertebr Pathol. 2007; 95:181-186. 
Special Conference Edition, November, 2019

Lacey, L. A. \& Siegel, J. P. (2000). Safety and ecotoxicology of entomopathogenic bacteria. In "Entomopathogenic Bacteria: From laboratory to field application" (J.-F. Charles, A. Delécluse, \& C. Nielsen-LeRoux, eds) pp. 253-273. Kluwer Academic Publishers, Dordrecht.

Lumsden, R. D., and Walter, J. F. (1995). Development of the biocontrol fungus Gliocladium virens: risk assessment and approval for horticultural use. In "Biological Control: Benefits and Risks" (H. M. T. Hokkanen and J. M. Lynch, eds.), pp. 263-269. Cambridge University Press, Cambridge, UK. Mol. Plant Pathol 4:297-305

Pathak, D. V, and Kumar, M. (2017). Microbial Pesticides: Development, Prospects and Popularization in India. (September 2018). https://doi.org/10.1007/978-98110-6593-4

Péchy-Tarr, M.; Bruck, D.J.; Maurhofer, M. Molecular analysis of a novel gene cluster encoding an insect toxin in plantassociated strains of Pseudomonas fluorescens. Environ.

Microbiol. 2008, 10, 2368-2386.

Rohrmann GF. (2013). Baculovirus Molecular Biology: Third Edition (Internet). Bethesda (MD): National Center for Biotechnology Information (US). Available online:
http://www.ncbi.nlm.nih.gov/books/NBK 114593/

Ruffner, B.; Péchy-Tarr, M.; Ryffel, F. Oral insecticidal activity of plant-associated pseudomonads. Environ.

Microbiol. 2013, 3, 751-763.

Slamet, U. (2015) 'Advantages And Disadvantages Of Microbial Control I World Agriculture'. Agrotechnopark.blogspot.sg. N.p., Web. 24 May 2015.

Srivastava KP and Dhaliwal GS. (2010) A Textbook of Applied Entomology. Kalyani Publishers, New Delhi, 113

Usta C. (2013)'Microorganisms In Biological Pest Control - A Review (Bacterial Toxin Application And Effect Of Environmental Factors)'. Current Progress in Biological Research (2013): n. pag. Web. 25 May 2015.

Access, O. (n.d.). We are IntechOpen, the world' $s$ leading publisher of Open Access books Built by scientists, for scientists TOP $1 \%$.

Kachhawa, D. (2017). Microorganisms as a biopesticides. 5(3), 468-473.

Pathak, D. V, \& Kumar, M. (2017). Microbial Pesticides: Development, Prospects and Popularization in India. (September 2018). https://doi.org/10.1007/978-98110-6593-4 